Article

\title{
Participatory Approach for More Robust Water Resource Management: Case Study of the Santa Rosa Sub-Watershed of the Philippines
}

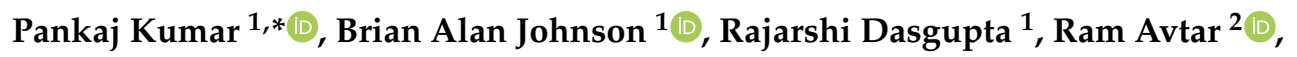 \\ Shamik Chakraborty ${ }^{3}$ (D), Masayuki Kawai ${ }^{1}$ and Damasa B. Magcale-Macandog ${ }^{4}$ \\ 1 Natural Resources and Ecosystem Services, Institute for Global Environmental Strategies, Hayama, \\ Kanagawa 240-0115, Japan; johnson@iges.or.jp (B.A.J.); dasgupta@iges.or.jp (R.D.); kawai@iges.or.jp (M.K.) \\ 2 Faculty of Environmental Earth Science, Hokkaido University, Sapporo 060-0810, Japan; \\ ram@ees.hokudai.ac.jp \\ 3 Faculty of Sustainability Studies, Hosei University, Tokyo 102-8160, Japan; \\ shamik.chakraborty.76@hosei.ac.jp \\ 4 Institute of Biological Sciences, University of the Philippines, Los Banos, Laguna 4031, Philippines; \\ dmmacandog@up.edu.ph \\ * Correspondence: kumar@iges.or.jp; Tel.: +81-046-855-3858
}

Received: 27 March 2020; Accepted: 16 April 2020; Published: 19 April 2020

\begin{abstract}
Due to the cumulative effects of rapid urbanization, population growth and climate change, many inland and coastal water bodies around the world are experiencing severe water pollution. To help make land-use and climate change adaptation policies more effective at a local scale, this study used a combination of participatory approaches and computer simulation modeling. This methodology (called the "Participatory Watershed Land-use Management" (PWLM) approach) consist of four major steps: (a) Scenario analysis, (b) impact assessment, (c) developing adaptation and mitigation measures and its integration in local government policies, and (d) improvement of land use plan. As a test case, we conducted PWLM in the Santa Rosa Sub-watershed of the Philippines, a rapidly urbanizing area outside Metro Manila. The scenario analysis step involved a participatory land-use mapping activity (to understand future likely land-use changes), as well as GCM precipitation and temperature data downscaling (to understand the local climate scenarios). For impact assessment, the Water Evaluation and Planning (WEAP) tool was used to simulate future river water quality (BOD and E. coli) under a Business as Usual (BAU) scenario and several alternative future scenarios considering different drivers and pressures (to 2030). Water samples from the Santa Rosa River in 2015 showed that $\mathrm{BOD}$ values ranged from 13 to $52 \mathrm{mg} / \mathrm{L}$; indicating that the river is already moderately to extremely polluted compared to desirable water quality (class B). In the future scenarios, we found that water quality will deteriorate further by 2030 under all scenarios. Population growth was found to have the highest impact on future water quality deterioration, while climate change had the lowest (although not negligible). After the impact assessment, different mitigation measures were suggested in a stakeholder consultation workshop, and of them (enhanced capacity of wastewater treatment plants (WWTPs), and increased sewerage connection rate) were adopted to generate a final scenario including countermeasures. The main benefit of the PWLM approach are its high level of stakeholder involvement (through co-generation of the research) and use of free (for developing countries) software and models, both of which contribute to an enhanced science-policy interface.
\end{abstract}

Keywords: water quality; WEAP; climate change adaptation; urbanization; domestic wastewater management; sustainable development goals 


\section{Introduction}

Population growth, rapid urbanization and climate change are continuously depleting finite fresh water resources, affecting both its quality and quantity [1]. Since institutional capacity are often limited, the threat of poor water quality, as well as unavailability of water, looms large on the horizon, particularly for developing countries [2,3]. To deal with future uncertainties in water quality and predict its future situation, scenario analysis through numerical quantification (using Integrated Water Resource Models) are of great significance, which may address key decision choices and facilitate targeted intervention. Nonetheless, water quality scenarios, as in other cases, requires trans-disciplinary approaches, including hydrological science, climate science, social science and local policies. It is imperative to ensure that local policy planners can understand, relate and utilize the hydrological modelling and scenario analysis at their respective watershed level, so as to prepare for a resilient future and achieve global targets, such as Sustainable developments goal 6.0 [4].

As a holistic approach, climate change adaptation actions at the watershed level are needed to reduce risks related to extreme hydro-meteorological weather conditions as well as to manage water quality and freshwater ecosystem [5]. For example, Proctor et al. [6] found that implementing a watershed management plan could be a win-win situation in terms of reducing water scarcity and generating economic revenue. At the national level, [7] found that a resilience-focused national strategy, consisting of broad-based resilience building across financial, human, social, natural and physical capital provides substantial future reduction of costs associated with climate disasters (El Niño).

Many researchers, in theory, argue that climate change adaptation and mitigation policies should be simultaneously developed to maximize their effectiveness, however, there is little understanding for how to do it in practice [8-12]. Holistic approaches to land-use planning and management, as well as incorporating other key drivers and pressures like climate change and population growth, may prove pivotal to bridge the adaptation and mitigation gaps, particularly against the backdrop of rapidly urbanizing developing countries.

The Philippines is a rapidly growing country (GDP over 7\%), but the growth has sustained uncoordinated rapid urban expansion, together with inadequate wastewater management infrastructure [13]. As a result, surface water resources remain under severe pressure due to direct discharge of wastewater. A series of extreme weather events, including floods and typhoons, further exacerbates the water quality deterioration. Nevertheless, only a couple of studies actually attempted to understand the status of water resources and their management strategies for the near future. Considering the gap in integrating climate change adaptation and mitigation measures into the land-use planning process at the watershed level, we indulged a multi-stakeholder participatory approach to develop a robust and resilient water resource management strategy. The present work was conducted in the Santa Rosa Sub-watershed, located near Metro Manila and alongside the Laguna de Bay lake (largest lake in the Philippines), and involved local governments as well as national agencies (the Laguna Lake Development Authority). We selected this study site because Santa Rosa City, the largest city within this watershed, is witnessing rapid industrial growth and expected to become the "Silicon Valley" and "Detroit" of the Philippines [14]. This also resulted in swift land use change, population influx and deterioration of water quality. So far, only a few scientific studies have addressed the water quality deterioration in this region using different methods like machine learning and/or time series analysis, and they found that river water was greatly polluted in reference to national guidelines $[15,16]$. However, the main limitations of the above studies were the limited period of observation and the lack of management guidelines both at short and long time scale. Looking in to the above knowledge gap, we have proposed an integrated approach also called "Participatory Watershed Land-use Management (PWLM) approach" to target water management issues from cradle to grave. This work will contribute to evidence-based policymaking (through giving meaningful inputs to local governments' "Local Climate Change Action Plans" and "Comprehensive Land Use Plans") related to sustainable water management by assessing the current and future water quality situation in the Santa Rosa River. We used a numerical simulation tool, the Water Evaluation and Planning (WEAP), to model river water quality under 
different scenarios. Finally, based on the hydrological simulation output, necessary adaptation and mitigation countermeasures and there inclusion in to local policy planning for four local government units within one watershed (Silang-Santa Rosa watershed) of the Laguna de Bay lake, Philippines.

\section{Study Area}

Santa Rosa is one of the major rivers that passes through cities of Biñan, Santa Rosa, Silang City, Cabuyao and very small portion of Tagaytay as shown in Figure 1. Annual rainfall in the study area is $1950 \mathrm{~mm}$ [17]. Population in Santa Rosa Watershed area is 641,884 as of year 2013 [18]. Whole area under the watershed is $108.2 \mathrm{Km}^{2}$ [5]. A Land Use/land cover map for the year 2014, developed through a supervised classification of a Landsat 8 image, indicated that the watershed is comprised of seven categories, namely: coconut (7\%), built up (25\%), forest ( $8 \%)$, grassland $(25 \%)$, industrial ( $9 \%$ ), mixed crop (8\%), and rice crop (17\%) [5]. For the modeling purpose, we have considered only four local government units (LGUs), i.e., Binan, Santa Rosa, Siland and Cabuyao, as the area of Tagaytay falling under the Santa Rosa sub-watershed is extremely small.

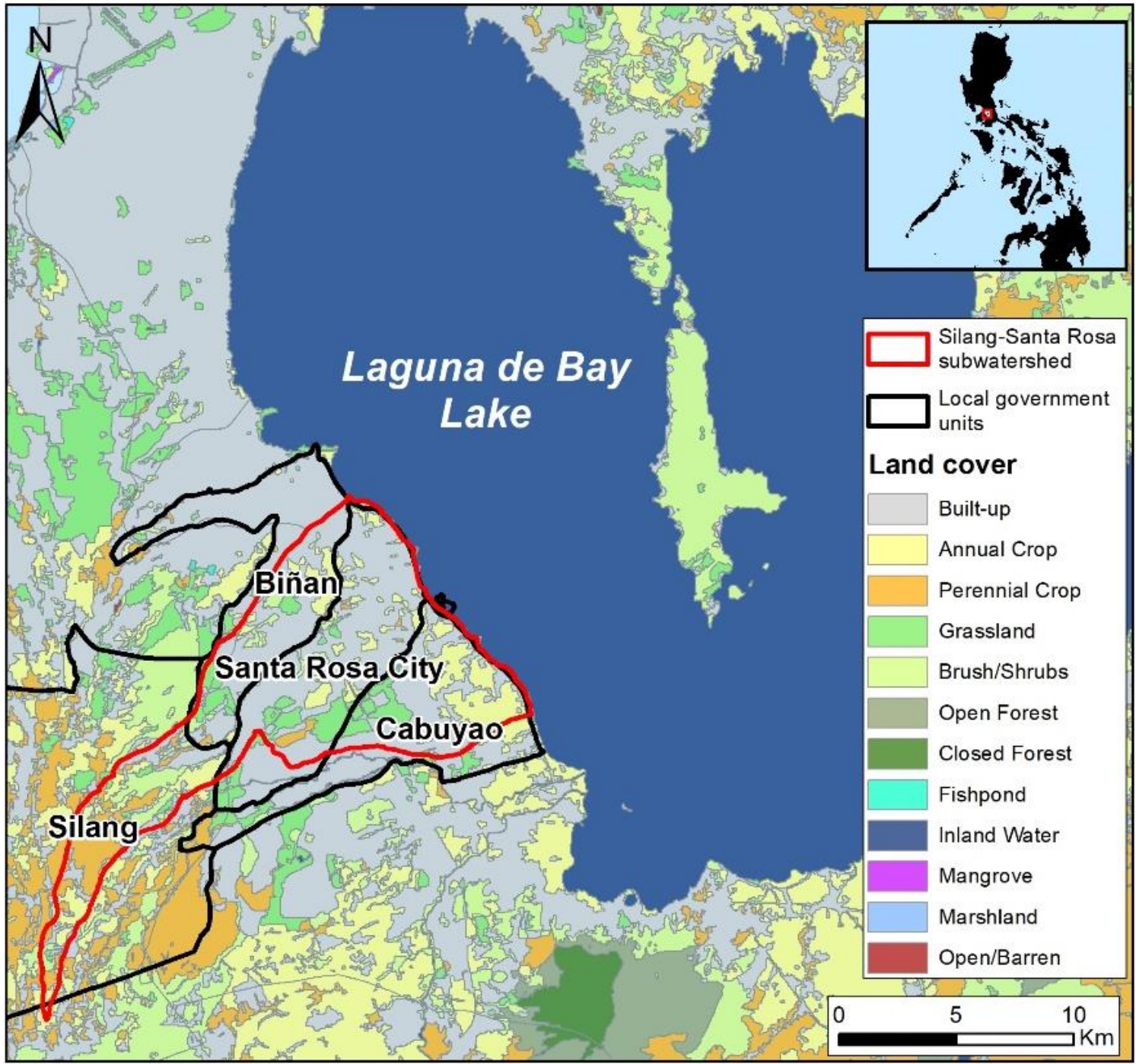

Figure 1. Santa Rosa watershed map. 


\section{Methodology}

\subsection{Participatory Watershed Land-Use Management (PWLM) Approach}

This approach consists of following four steps: (i) Scenario analysis, (ii) impact assessment, (iii) Climate change adaptation and mitigation (CCA\&M) measure development, and (iv) Land-use plan improvement (Figure 2).

1. The first step, scenario analysis, aims at understanding the problems that the local governments face in terms of water quality deterioration, as well as the future land-use and development plans of the city/municipality. For this analysis, participatory rapid appraisal activities including key informant interviews, focus group discussions, and participatory land-use mapping, are conducted with representatives from each LGU. The government officials participating in these discussions typically come from different departments, including urban planning, agriculture, environment, and disaster risk reduction and water resource management. Through key informant interviews and focus group discussion, we identified the main issues pertaining water resource in terms of both quality and quantity, using basic sets of questions. For the participatory mapping, officials produce a map of the land-use changes expected to occur over the next decade (until 2030) by sketching the future land conversions on a (poster-sized) sheet of tracing paper overlaid onto the current land-use map. This information is later digitized and georeferenced using Geographical Information Systems (GIS) software as shown in Figure 2.

2. The second step, impact assessment, involves estimating the impacts of the planned land-use changes, climate change and population growth on water quality. For this, Water Evaluation and Planning (WEAP), an integrated water resource management (IWRM) hydrological model, was used. The WEAP model is capable to estimate both water quality and quantity using scenario analysis. The other reason to select this model was that it is free for developing countries, hence easy for the hydrological officers to replicate such studies by themselves after capacity development.

3. The third step, CCA\&M measure development, aims to devise possible climate actions for both adaptation and mitigation in consultation with the local governments, and prioritize these actions according to their feasibility and urgency. Another focus group discussion (FGD) session was organized including participants from Water Quality Management Authority (WQMA) board members, Laguna Lake Development Authority (LLDA) (a prime nodal agency dedicated to water resource management in and around Laguna De Bay area) officials from environment and water divisions, environmental officers in-charge of water management from four LGUs falling within Santa Rosa river watershed. We requested the officials to identify measures based on the needs of each local government. Through this FGD, a set of possible countermeasures like building wastewater treatment plants (WWTPs), river rehabilitation, reduction in industrial effluent discharge without treatment were presented. Further consultation then led to the identification of priority measures.

4. Step four, land-use plan improvement, aims to support local governments to strengthen their land-use and related development plans through dialogue on the recommendations generated from the previous three steps. At present, there is no adaptation and mitigation measures for water quality improvement, mentioned in the LGUs' land-use plans. Therefore, we have evaluated the hypothetical installation of WWTPs of capacity 164MLD and its impact on water quality improvement. Based on the positive simulation result we got, suggestions were provided to local government units (LGUs) policy documents i.e., Comprehensive land use plan (CLUP) [19] or Local climate change action plan (LCCAP). 


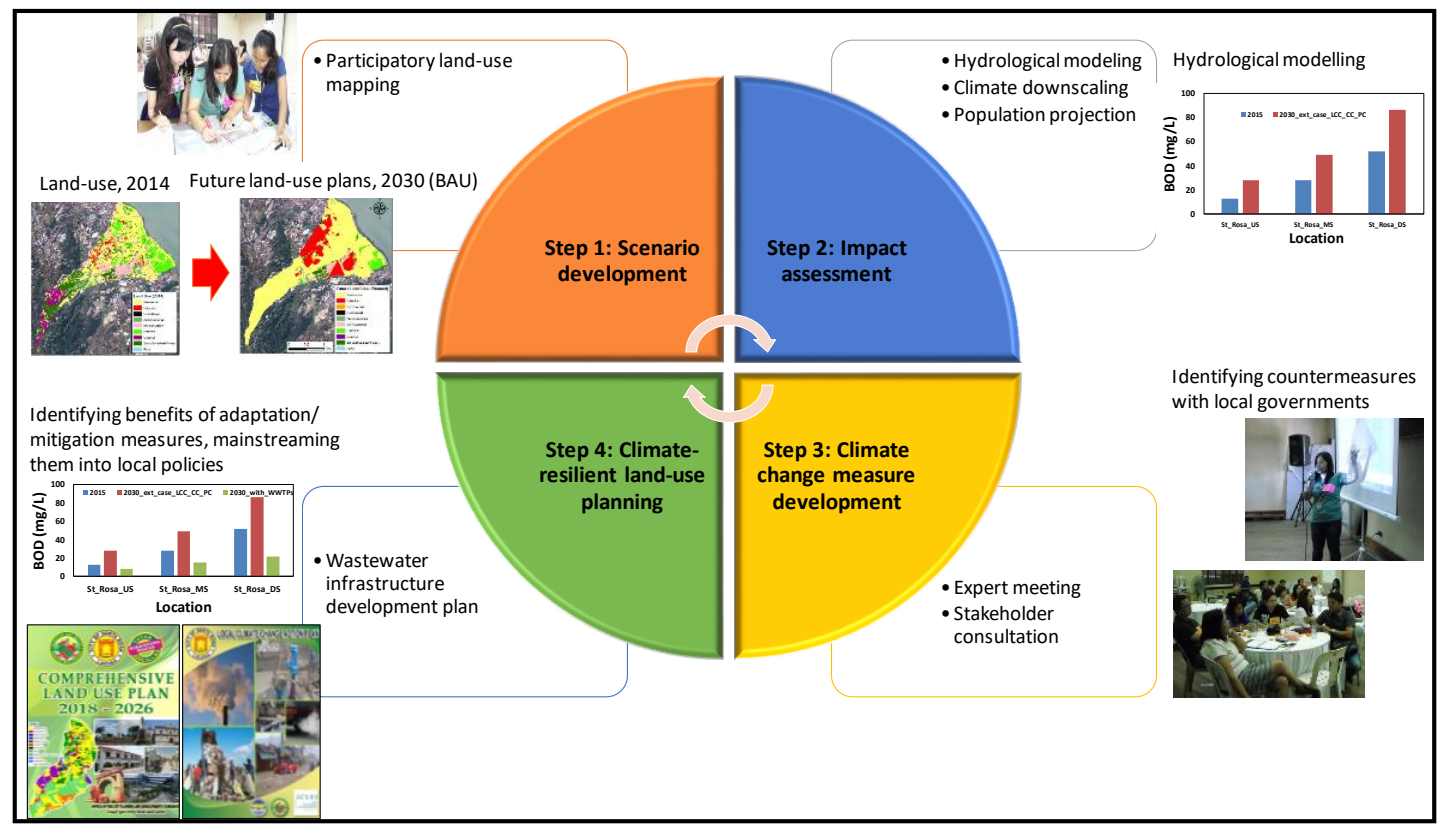

Figure 2. Research methodology.

\subsection{Hydrological Model}

WEAP model is used to simulate river discharge and water quality variables. Using GIS files for administrative boundary of the study area and drainage network, schematic diagram was developed. Whole study area is divided into smaller catchments based on the topographical, hydrological, confluence points, and climatic characteristics of the river basin Different catchment methods, namely rainfall runoff (simplified coefficient method), irrigation demands only (simplified coefficient method) and rainfall runoff (soil moisture method) that are available in the WEAP platform enable it to simulate different components of hydrological cycle including the catchment's potential evapotranspiration (by using crop coefficients), surface runoff and infiltration of rainfall. Based on the data availability, the rainfall runoff method (simplified coefficient method), is used for the catchment simulation [20].

Streeter-Phelps model within WEAP was used to estimate pollution concentrations in water bodies. Simulation of oxygen balance in a river within this model is governed by two processes i.e., consumption by decaying organic matter and reaeration induced by an oxygen deficit. The removal BOD from water is a function of water temperature, settling velocity, and water depth Equations (1) and (2):

$$
\begin{gathered}
B O D_{\text {final }}=B O D_{\text {init }} \exp \frac{-k_{r B O D} L}{u} \\
k_{r B O D}=k_{d 20}{ }^{1.047(t-20)}+\frac{v_{s}}{H}
\end{gathered}
$$

where $B O D_{\text {init }}=B O D$ concentration at the top of the reach $(\mathrm{mg} / \mathrm{L}), B O D_{\text {final }}=B O D$ concentration at the end of the reach $(\mathrm{mg} / \mathrm{L}), t=$ water temperature (in degrees Celsius), $H=$ water depth $(\mathrm{m}), \mathrm{L}=$ reach length $(\mathrm{m}), \mathrm{U}=$ water velocity in the reach, $v_{\mathrm{s}}=$ settling velocity $(\mathrm{m} / \mathrm{s}), \mathrm{k}_{\mathrm{r}}, \mathrm{k}_{\mathrm{d}}$ and $\mathrm{k}_{\mathrm{a}}=$ total removal, decomposition and aeration rate constants $\left(1 /\right.$ time), $\mathrm{k}_{\mathrm{d} 20}=$ decomposition rate at reference temperature (20 Celsius).

\section{Data Requirement for Model Set Up}

Scenario based future (year 2030) prediction of the water quality is done to visualize plausible alternative water management policies in the Santa Rosa River. Datasets used for the modeling were domestic wastewater discharge, past River water quality at different monitoring stations, population, rainfall, temperatures, river cross section, river length, river discharge, land use/land cover etc. 
For water quality parameters, we have used biochemical oxygen demand (BOD) and total coliforms (which was later assumed as equivalent to Escherichia coli counts) collected at three points on Santa Rosa River. Data for both water quality parameters was analyzed by LLDA following the standard method of water quality analysis from APHA [21]. Principal reasons for selecting sampling locations were the accessibility of water samples, saving cost and to observe effect of urbanization at approximately equidistant throughout the river length passing through the watershed. For hydrological modeling, four catchment areas in the Santa Rosa watershed, which experienced inter-basin transfers were considered. Pollutant transport from a catchment accompanied by rainfall-runoff is enabled by ticking the water quality modeling option During non-rainy days, pollutants accumulate on the catchment surfaces and reach water bodies through surface runoff. Regarding future precipitation data, three different Global Climate Models (GCMs) (MRI-CGCM3, MIROC5, HadGEM-ES) and Representative Concentration Pathway (RCP) (4.5 and 8.5) output were used after downscaling and bias correction., We have evaluated average value of the change in monthly average precipitation for both RCP 4.5 and 8.5 in order to evaluate the climate change on water quality. The whole study area is divided into four demand sites for estimating the effect of population growth and its associated domestic wastewater discharge on river water quality status. Primarily, these demand sites denotes population of different LGUs lying on either side of the Santa Rosa River within our study area. Future population in these demand sites were estimated by ratio method using UNDESA projected growth rate [22]. In the absence of exact information on the total domestic wastewater production, the daily volume of domestic wastewater generation per person considered for this study was 130 liters [23]. Whole simulation process is divided in three phases: (a) Model set-up and data input, (b) calibration and validation, and (c) future simulation using scenario analysis. Schematic diagram for the model set-up is shown in Figure 3.

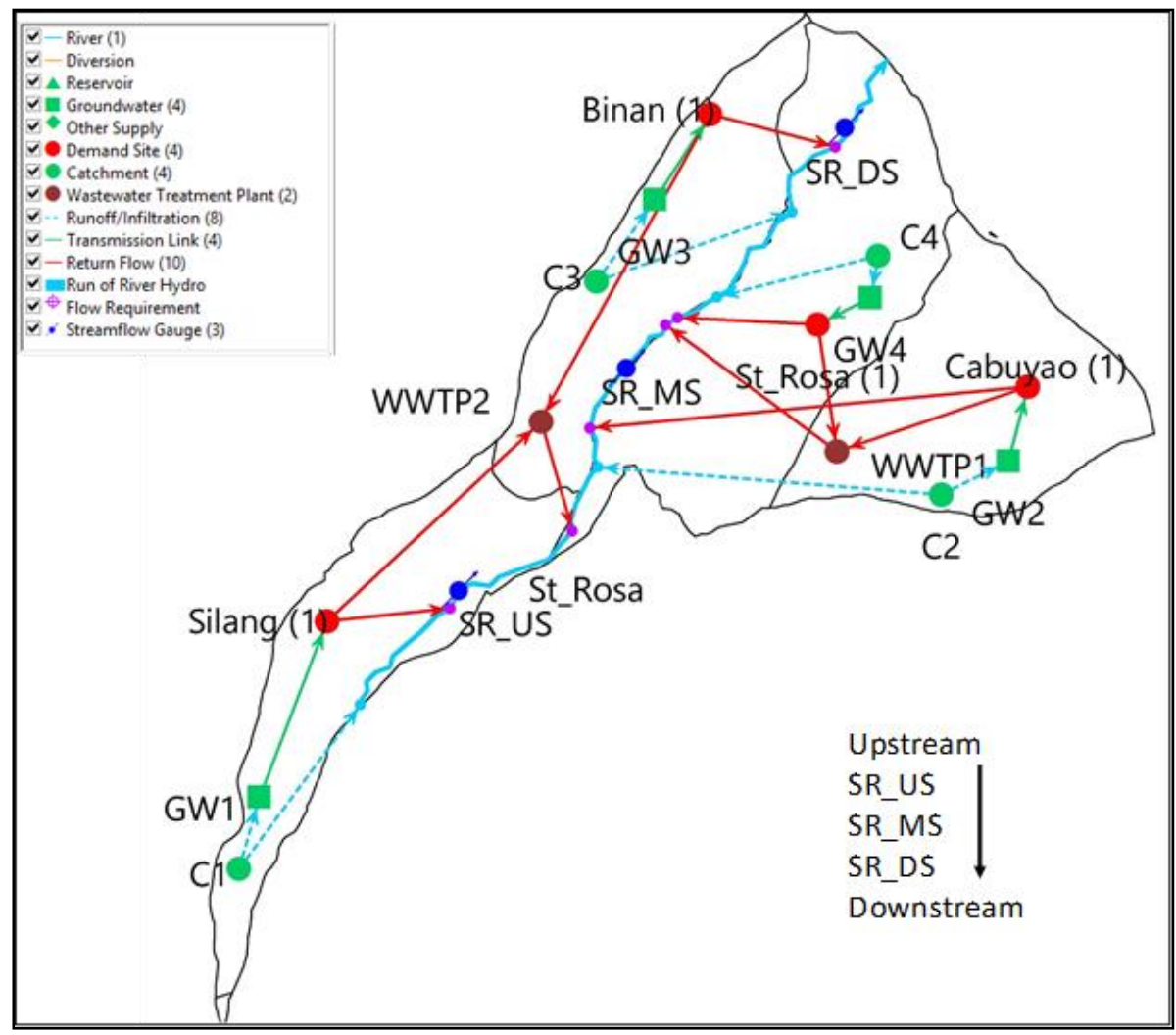

Figure 3. Schematic diagram showing the problem domain for water quality modeling in Santa Rosa River using Water Evaluation and Planning (WEAP) interface. Here, WWTP-Wastewater treatment plant, SG-Stream gauge, C-Catchment, GW-Groundwater. 


\section{Results and Discussion}

\subsection{Future Prediction of Key Drivers and Pressures}

For this study, three drivers and pressures i.e., population growth, climate change and land use land cover were considered to estimate impact of its change in water quality. Here source for current population (2013) data is Philippine Statistics Authority, while future population is estimated with growth rate provided by UNDESA [22]). UNDESA provides future population of different countries for different administrative levels with population growth rate at every five years. This growth rate is predicted based on the population growth in past twenty years, rate of economic growth, industrial growth and other likely factors. We have also adopted these population growth rate to predict population of the study area and result is show in Figure 4. It is found that total population, which was 638,711 in year 2013, will be projected to grow to 1,283,202 by year 2030 .

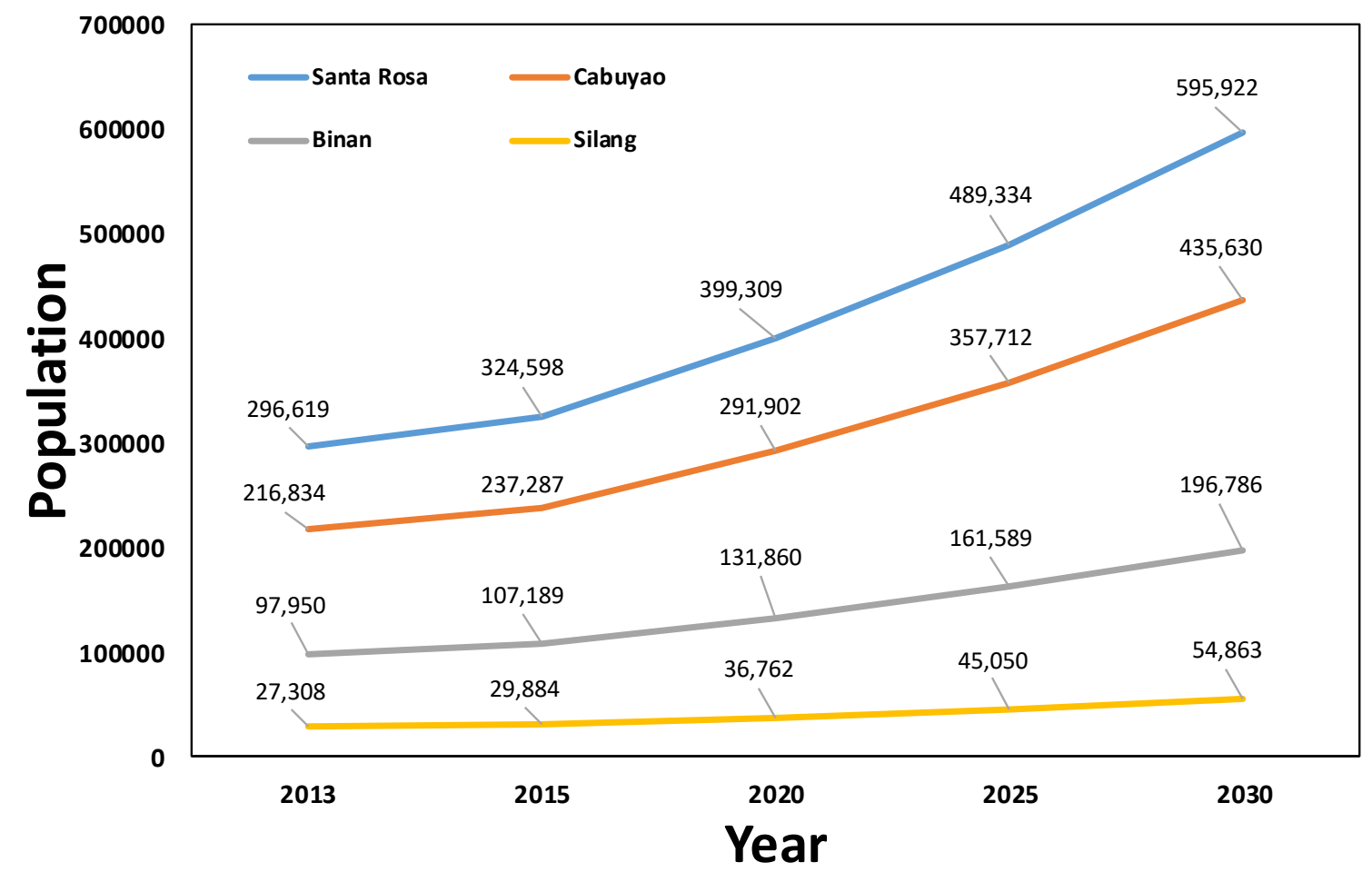

Figure 4. Plot showing trend in population growth in the study area.

A summary of the observed and projected monthly precipitation ( $\mathrm{mm}$ ) values after climate downscaling is presented in Figure 5. For annual precipitation, the observed value for the year 2015 was $2803.2 \mathrm{~mm}$. On the other hand, projected annual precipitation values for the year 2030 using different GCMs and RCPs ranged from 1658.5 to $2806.9 \mathrm{~mm}$. The output from the HadGEM-ES GCM showed a sharp decrease in precipitation, especially during summer month, which was considered as an anomaly and hence not included during our scenario building. Looking at the outputs from other GCMs (MRI-CGCM and MIROC5), it was clear that the annual precipitation projected from GCM downscaling is not much different from the current observed value. However, looking carefully, there is some difference between these values at the monthly scale. Therefore, in this research, we wanted to estimate whether this small changes on precipitation has any significant changes on the water quality or not. 


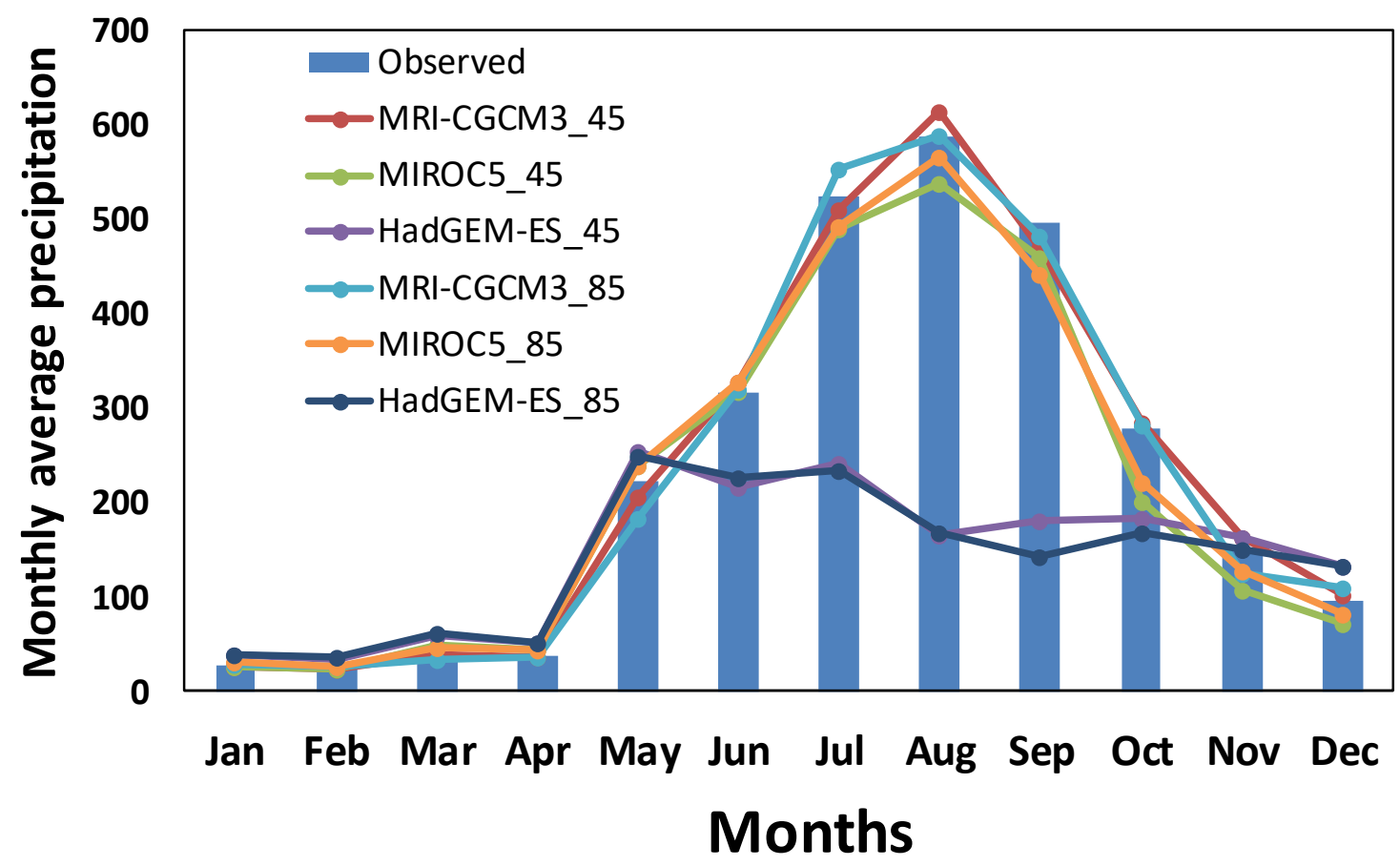

Figure 5. Comparison between observed and downscaled Global Climate Models (GCMs) output for monthly average rainfall. Here three GCMs used are MRI-CGCM, MIROC5 and HadGEM-ES. Suffix 45 and 85 represents RCP 4.5 and 8.5 used here.

Other drivers used to observe water quality deterioration was land use land cover change and the result is shown are shown in Figure 6. From the figure, it is found that among five different land use land cover classes; only built-up is showing positive changes i.e., percentage share of built-up area to the total area is increasing. Also, this change is happening at the expanse of decrease in agriculture, idle land/grassland, rice field and tree. Further, percentage increase in built-up area will be maximum for Silang followed by Cabuyao, Binan and Santa Rosa. In case of loss of agricultural land, highest change was observed for Silang, followed by Cabuyao, Santa Rosa and Binan. For percentage reduction in the idle land/grassland the order was Silang, Cabuyao, Binan and Santa Rosa. Looking into the percentage reduction of rice field, both Binan and Santa Rosa are suffering most followed by Cabuyao, where Silang is least impacted. Looking into the percentage reduction in tree cover the order was Silang, Binan, Cabuyao, and Santa Rosa. 


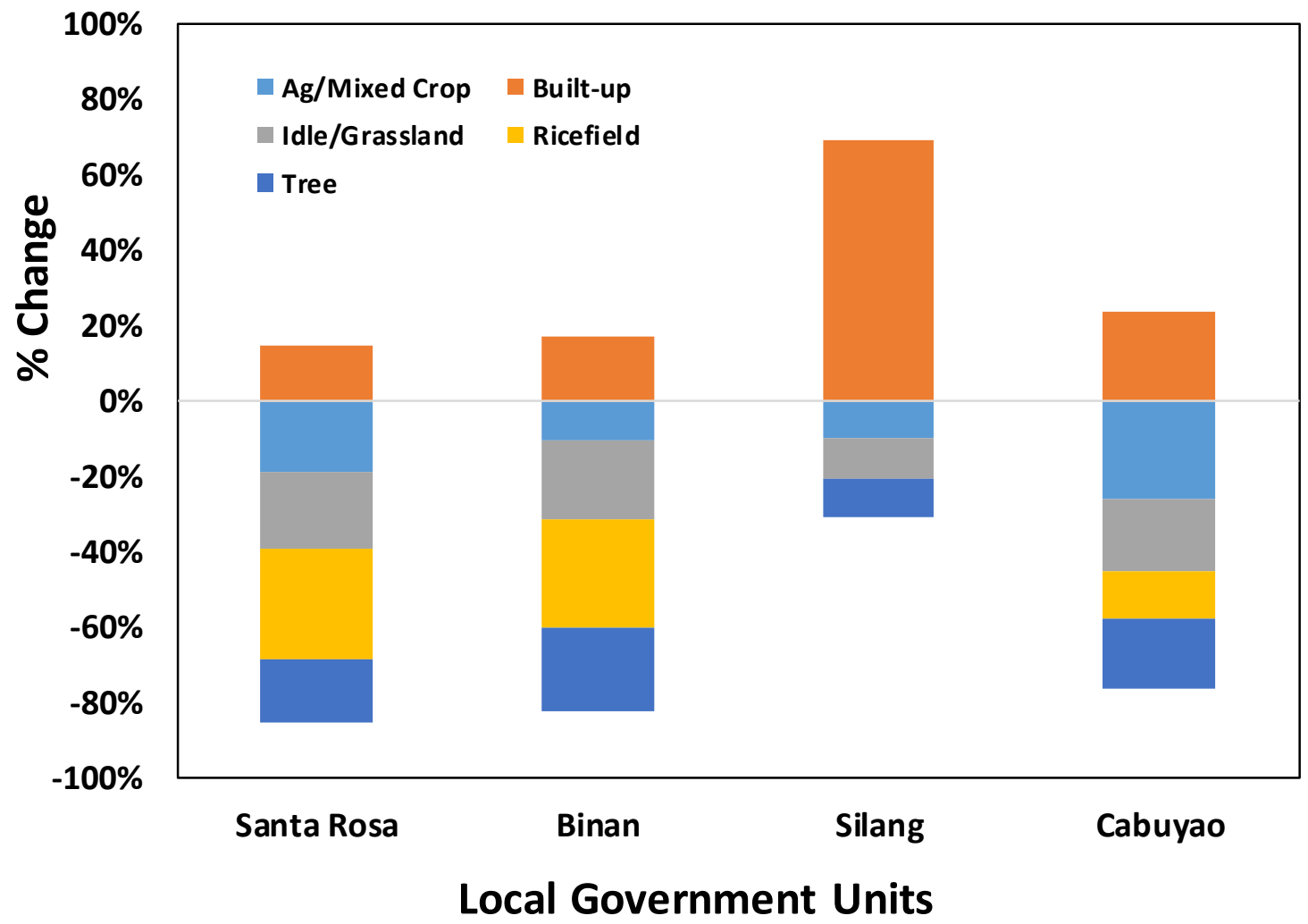

Figure 6. Percentage of land use land cover change among four different local government units (LGUs) coming within Santa Rosa sub-watershed.

\subsection{Hydrological Simulation Using WEAP}

\subsubsection{Model Performance Evaluation}

Before doing future simulation, it is important to check the performance credibility of the WEAP model through calibration and validation. For model validation, stream flow and BOD were used for hydrological and water quality components respectively. For calibration, trial and error method was applied during simulation in order to get best-fit results. Mainly effective precipitation and runoff/infiltration were adjusted to reproduce the observed monthly stream flows for the year of 2015 (Table 1). The final best-fit values for both entities was $92 \%$ and $55 / 45$ respectively. Validation result for both stream flow and BOD is shown in Figure 7a,b respectively. Figure 7a, shows a relation of monthly simulated and observed stream flows for Santa Rosa midstream station. Significant association was found for most of the months with correlation coefficient $\left(R^{2}\right) \cong 0.78$, root-mean-square error (RSME) $\cong 0.23$, and an average error of $13 \%$. For water quality validation, both simulated and observed concentration of BOD from the year 2014 was considered. Here, also results show a strong relation between observed and simulated BOD concentrations (with error of $14 \%$ ) (Figure $7 \mathrm{~b}$ ) authorizing credibility of the model performance in study area. Selection of year 2015 and 2014 for stream flow and BOD respectively, were made because of the observed data availability.

Table 1. Summary of parameters and steps used for calibration.

\begin{tabular}{cccc}
\hline Parameter & Initial Value & Step & Final Value \\
\hline Effective precipitation & $100 \%$ & $\pm 0.5 \%$ & $92 \%$ \\
Runoff/infiltration ratio & $50 / 50$ & $\pm 5 / 5$ & $55 / 45$ \\
\hline
\end{tabular}




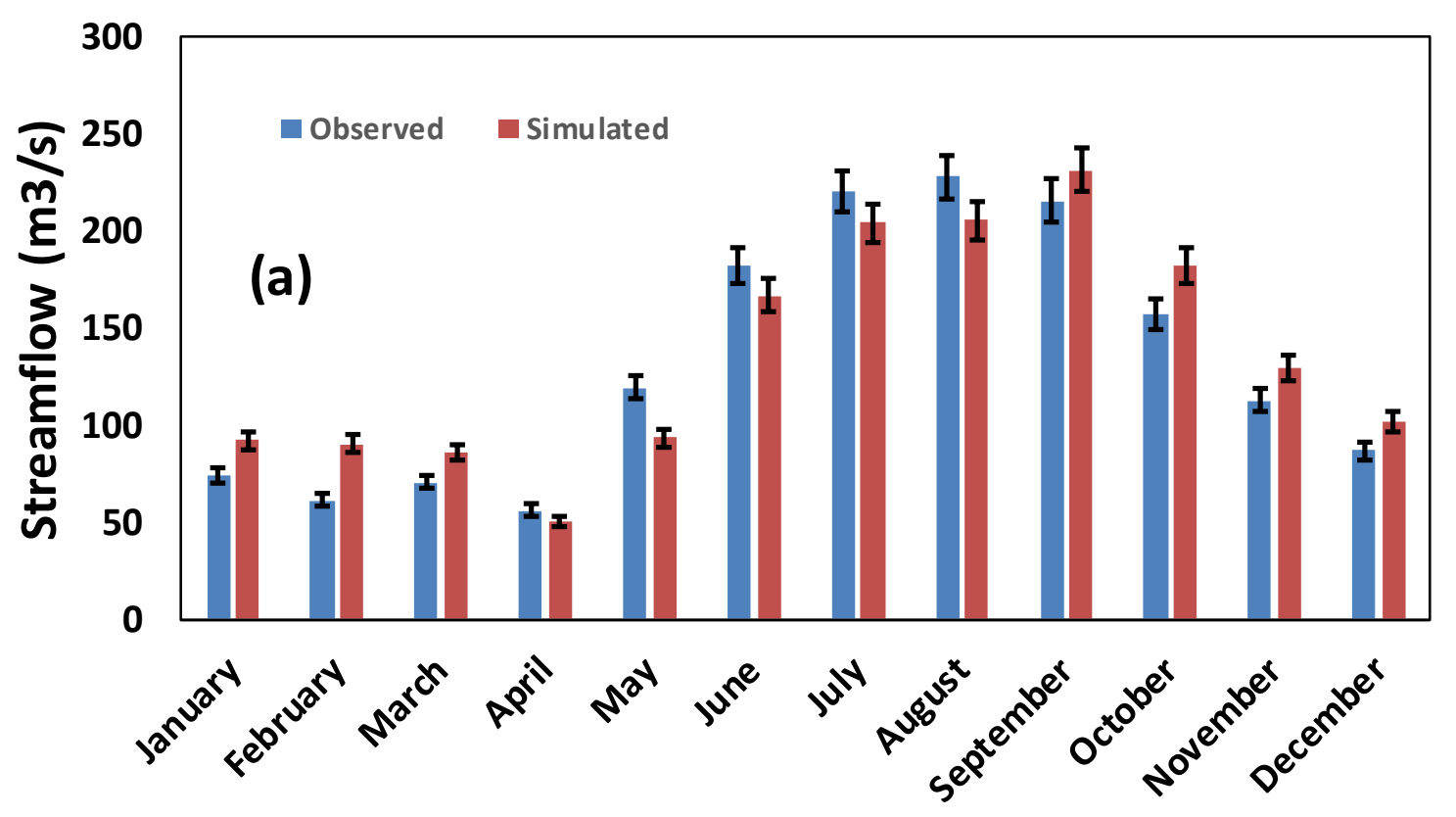

Months

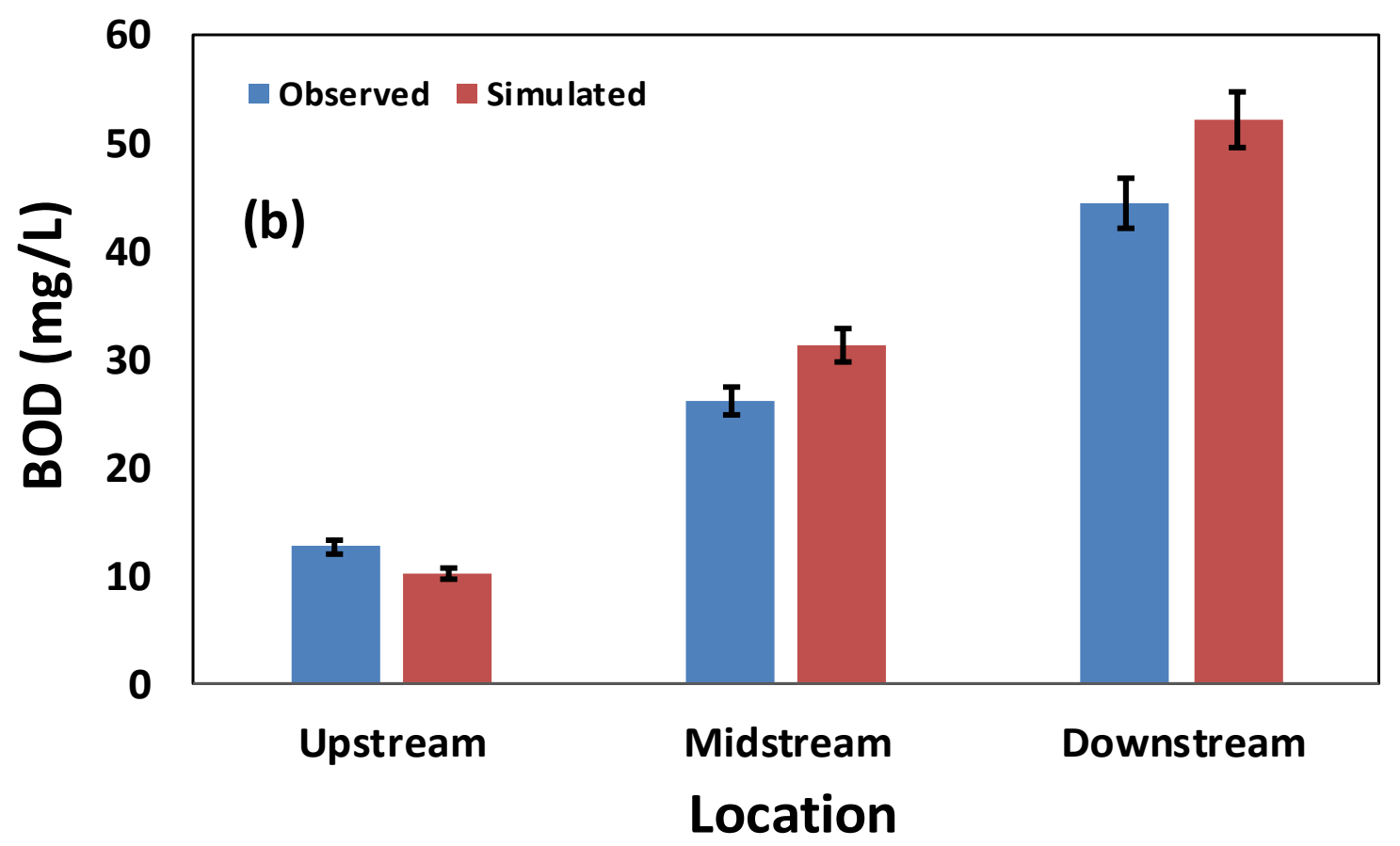

Figure 7. Validation of the model output by comparing simulated and observed (a) average monthly river discharge for year 2015 at Santa Rosa midstream; (b) average biochemical oxygen demand (BOD) values for different locations for the year 2014. Here small vertical black lines on the top of the bars are showing percentage error.

\subsubsection{Scenario Analyses}

For water quality, simulation is done using two scenarios namely future scenario without adaptation measures (for the risk assessment i.e., step two of PWLM) and future scenarios with adaptation measures (after the stakeholders for identifying countermeasures i.e., step three).

For impact assessment, we have considered all three drivers and pressures. Five sets of simulated concentration were obtained considering following "what-if" situations without adaptation measures, 
(a) with population growth only; (b) with population growth and moderate climate change; (c) with population growth and extreme climate change; $(d)$ with population growth, moderate climate change and land use land cover change; and (e) with population growth, extreme climate change and land use land cover change. Result obtained through hydrological simulation were compared with national guideline for class B i.e., swimmable category (BOD $<3 \mathrm{mg} / \mathrm{L}$ and E. coli $<500 \mathrm{CFU} / 100 \mathrm{~mL}$ ) [24] is shown in Figure 8.

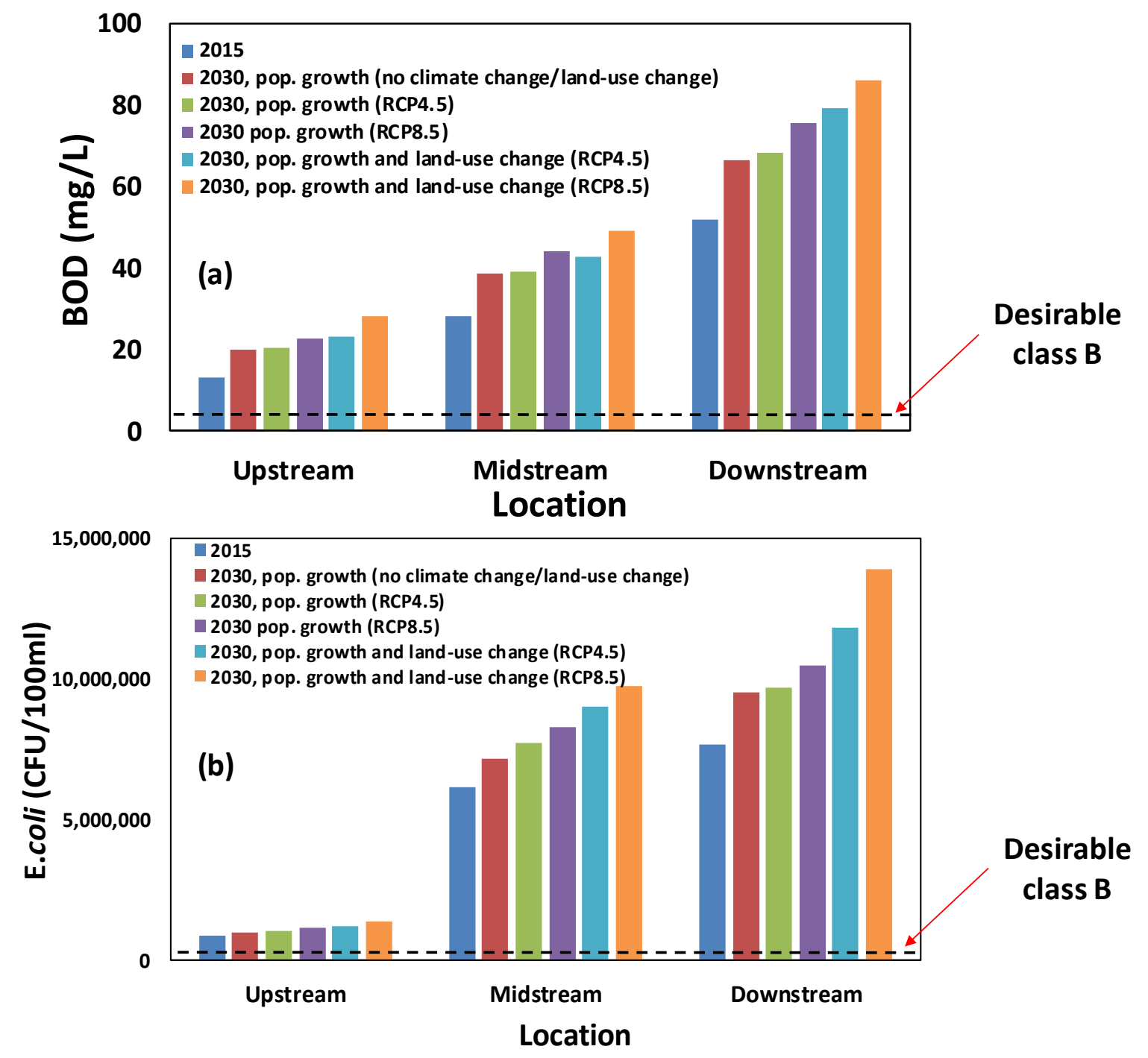

Figure 8. Result shows simulated water quality parameters (a) BOD (b) E. coli for future scenario without adaptation measures.

Simulated concentration of BOD for year 2015 varies from 13 to $52 \mathrm{mg} / \mathrm{L}$. When compared to the desirable concentration of BOD from Class B, it can be said that all samples throughout the year falls under moderately to extremely polluted category. Average percentage increase in the BOD and E. coli by 2030 is $76 \%$ and $104 \%$ respectively when compared with situation in 2015 . Looking into the result from future scenarios, it is found that the effect of all climate change, land use/land cover change and population changes are prominent in water quality status and water quality will deteriorate further in 2030 when compared to the current situation. We have further analyzed the impact of individual drivers and pressure on water quality deterioration and result is shown in Table 2. It was found that, the order of average deterioration effect of water quality (both for BOD and E. coli) due to population growth, climate change and land use/land cover change were population growth $>$ land 
use/land cover change $>$ climate change. This result can be explained, as amount of wastewater being generated will grow automatically with population increase without any countermeasures. On the other hand, land use land cover change as well as climate change induced extreme weather condition will trigger the changes in River discharge. This change in River discharge will cause change in water quality parameters due to oxidation-reduction process. This clearly depicts that building any local climate resilient plan must consider these three key drivers and pressures which likely to impact water resources. Although effect of climate change is not huge but it is significant enough to make the local master plan more robust for sustainable future water environment. In addition, based on the simulated water quality, river water likely to pose potential health risks like gastroenteritis if consumed accidently (microbial contamination), and death of aquatic organisms like fish (because of high BOD).

Table 2. Summary for order of contribution of different drivers on water quality deterioration in Santa Rosa sub-watershed.

\begin{tabular}{ccccc}
\hline Parameter & $\begin{array}{c}\text { Average \% Increase } \\
\text { (2015 to 2030) }\end{array}$ & $\begin{array}{c}\text { \% Contribution from } \\
\text { Population Growth }\end{array}$ & $\begin{array}{c}\text { \% Contribution from } \\
\text { LULC Change }\end{array}$ & $\begin{array}{c}\text { \% Contribution from } \\
\text { Climate Change }\end{array}$ \\
\hline BOD & 76 & 66 & 23 & 11 \\
E. coli & 104 & 71 & 20 & 9 \\
\hline
\end{tabular}

\subsubsection{Scenario with Adaptation Measures}

In step three of PWLM, an experts meeting and stakeholder consultation workshop was organized to identify possible countermeasures to mitigate the expected water quality deterioration. Participants were governmental officials from department of water resources, environment, irrigation, fisheries, infrastructure etc., both at national and provincial level; consultants, NGOs, academia. List of possible countermeasures, which were discussed were: (a) Building Wastewater Treatment Plants (WWTPs) and sewerage connection to each households, (b) cleaning the riverfronts, (c) strict regulation on discharge of untreated/partially treated industrial effluents to the waterbodies, (d) diligent monitoring (sampling and analysis) of water quality, (e) minimizing the human impacts on river catchment areas etc.

In this study, we have quantified the effect of first suggested countermeasure i.e., Building Wastewater Treatment Plants (WWTPs) and sewerage connection to each households. Here the capacity of WWTP was decided based on the projected wastewater discharge by year 2030, which was 166,816,291 liter of wastewater generated per day. Hence, we have considered two WWTPs of combined capacity of 164 MLD estimated as shown in Table 3. All considered WWTPs are of Upflow Anaerobic Sludge Blanket Reactor Coupled with Sequencing Batch Reactor (UASB-SBR) type. These WWTPs are designed with high contaminant removal efficiency as $97 \%$ for BOD and $99.69 \%$ for fecal coliform [25]. In addition, we have also considered $100 \%$ sewerage connection rate.

Table 3. Summary for WWTPs considered for the scenario building.

\begin{tabular}{cccc}
\hline WWTP & Future Population (2030) & $\begin{array}{c}\text { Wastewater Generated } \\
\text { in Liter Per Day for the } \\
\text { Year 2030@130 } \\
\text { liter/capita/day }\end{array}$ & $\begin{array}{c}\text { WWTP Capacity in } \\
\text { Million Liter Per Day } \\
\text { (MLD) Assumed for } \\
\text { Numerical Simulation }\end{array}$ \\
\hline $\begin{array}{c}\text { WWTP 1 (will serve Santa Rosa } \\
\text { and Cabuyao) }\end{array}$ & $1,031,553$ & $134,101,847$ & 134 \\
$\begin{array}{c}\text { WWTP 2 (will serve Binan } \\
\text { and Silang) }\end{array}$ & 251,650 & $32,714,443$ & 32 \\
\hline
\end{tabular}

Based on the above assumption, water quality for scenario with countermeasures was simulated and the result is shown in Figure 9. Simulated value of BOD ranged from 8 to $17 \mathrm{mg} / \mathrm{L}$ and average BOD reduction of 62 percent when compared with current status. On the other hand, simulated value of E. coli ranging from 35,783 to $112,948 \mathrm{CFU} / 100 \mathrm{~mL}$ with an average reduction of 98 percent when compared to current situation. Although water quality improved a lot which is an encouraging 
sign but to achieve water quality of Class B, government need to adopt more than one adaptation measures together.

Finally, suggestions for adaptation measures with scientific evidence of their impact were communicated to the Local Government Officials to incorporate this suggestion in their policy documents like i.e., Comprehensive land use plan (CLUP) or Local climate change action plan (LCCAP) for sustainable water resource management [19].
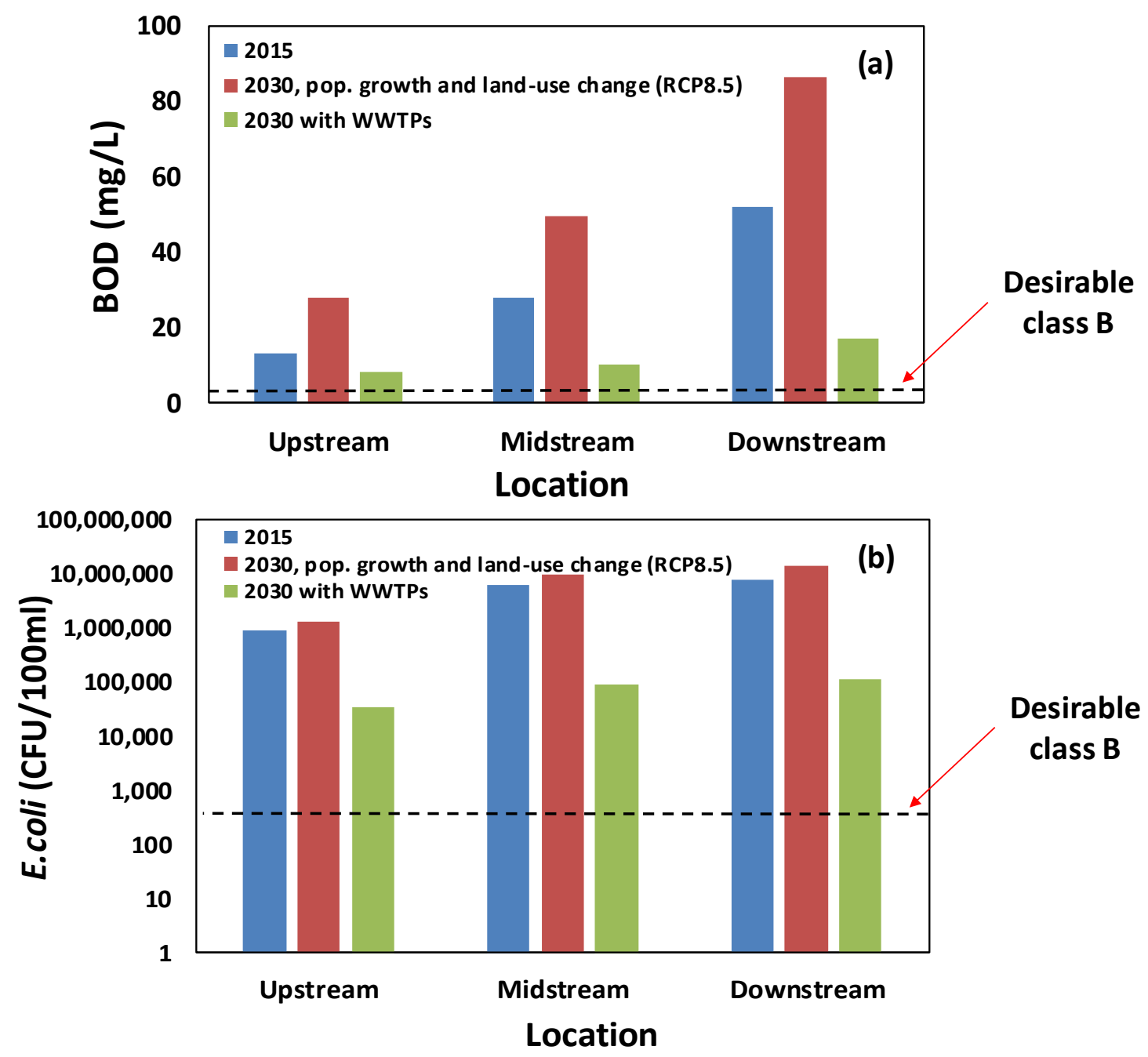

Figure 9. Result shows simulated water quality parameters (a) BOD (b) E. coli for scenario with adaptation measures.

\section{Conclusions}

Although there are typically multiple institutions dealing with land-use and water quality issues within a watershed (e.g., local and provincial governments, NGOs, and private companies), disconnects and/or redundancies often occur in their work, which presents a major obstacle in institutional set-up. Therefore, a transdisciplinary and integrated (both bottom-up and top-down) approach should be employed for solving this complex issue of water resource management. Along these lines, this study emphasized that the Participatory Watershed Land-use Management (PWLM) approach can aid the sustainable management of water resources if all the key stakeholders and LGUs involved work in a holistic manner rather in silos. Hydrological simulation presented a clear picture for the current status as well as future prediction of water quality throughout the Santa Rosa River using scenario analysis. The PWLM approach provides an integrated framework for water resource management, 
where retrofitting models are being developed with regular feedbacks of different stakeholders to meet their need and to feel ownership of the simulated results. Although PWLM has been applied in a previous work to estimate the impacts of land-use change and climate change on urban flooding [5], this is the first study to utilize PWLM for water quality assessment and management. As the number of sampling locations used is relatively few in this study (and in the area around the Laguna de Bay lake in general), more sampling locations along with increased frequency of monitoring (as well as monitoring of additional organic/inorganic water quality parameters) should be a priority to promote for further studies in this critical region.

Author Contributions: Conceptualization, P.K., B.A.J.; methodology, P.K., B.A.J.; investigation, P.K., B.A.J.; writing, P.K., B.A.J.; writing-review and editing, P.K., B.A.J., R.D., R.A., S.C., M.K., D.B.M.-M. All authors have read and agreed to the published version of the manuscript.

Funding: This research received no external funding.

Acknowledgments: This paper is generally based upon outputs produced under the "Adaptation Initiative" project for the fiscal year 2019, commissioned work of the Japanese Ministry of the Environment. We also show our appreciation for the participation of LGU officials from the four units (Santa Rosa, Silang, Cabuyao, Binan), support and data from LLDA, and the support from the Institute of Biological Sciences, University of Philippines, Los Banos.

Conflicts of Interest: The authors declare no conflict of interest.

\section{References}

1. Mekonnen, M.M.; Hoekstra, A.Y. Four billion people facing severe water scarcity. Sci. Adv. 2016, 2, e1500323. [CrossRef] [PubMed]

2. Hosseini, N.; Johnston, J.; Lindenschmidt, K. Impacts of climate change on the water quality of a regulated Prairie River. Water 2017, 9, 199. [CrossRef]

3. Kumar, P.; Masago, Y.; Mishra, B.K.; Fukushi, K. Evaluating future stress due to combined effect of climate change and rapid urbanization for Pasig-Marikina River, Manila. Groundw. Sustain. Dev. 2018, 6, 227-234. [CrossRef]

4. Kumar, P. Numerical quantification of current status quo and future prediction of water quality in eight Asian Mega cities: Challenges and opportunities for sustainable water management. Environ. Monit. Assess. 2019, 191, 319. [CrossRef] [PubMed]

5. Endo, I.; Magcale-macandog, D.B.; Kojima, S.; Johnson, B.A.; Bragais, M.; Beatrice-macandog, P.; Scheyvens, H. Participatory land-use approach for integrating climate change adaptation and mitigation into basin scale local planning. Particip. Sustain. Cities Soc. 2017, 64, 184-193. [CrossRef]

6. Procter, A.; McDaniels, T.; Vignola, R. Using expert judgments to inform economic evaluation of ecosystem-based adaptation decisions: Watershed management for enhancing water supply for Tegucigalpa, Honduras. Environ. Syst. Decis. 2017, 37, 410-422. [CrossRef]

7. French, A.; Mechler, R. Managing El Niño Risks Under Uncertainty in Peru: Learning from the Past for a More Disaster-resilient Future; International Institute for Applied Systems Analysis: Laxenburg, Austria, 2017.

8. IPCC. Climate Change 2014: Synthesis Report; Contribution of Working Groups I, II and III to the Fifth Assessment Report of the Intergovernmental Panel on Climate Change; Core Writing Team, Pachauri, R.K., Meyer, L.A., Eds.; IPCC: Geneva, Switzerland, 2014; p. 151.

9. Jones, R.; Patwardhan, A.; Cohen, S.; Dessai, S.; Lammel, A.; Lempert, R.; Mirza, M.M.Q.; von Storch, H. Foundations for decision making. In Climate Change 2014: Impacts, Adaptation, and Vulnerability. Part A: Global and Sectoral Aspects; Contribution of Working Group II to the Fifth Assessment Report of the Intergovernmental Panel on Climate Change; Field, C.B., Barros, V.R., Dokken, D.J., Mach, K.J., Mastrandrea, M.D., Bilir, T.E., Chatterjee, M., Ebi, K.L., Estrada, Y.O., Genova, R.C., et al., Eds.; Cambridge University Press: Cambridge, UK; New York, NY, USA, 2014; pp. 195-228.

10. Duguma, L.A.; Wambugu, S.W.; Minang, P.A.; van Noordwijk, M. A systematic analysis of enabling conditions for synergy between climate change mitigation and adaptation measures in developing countries. Environ. Sci. Policy 2014, 42, 138-148. [CrossRef] 
11. Wilbanks, T.; Sathaye, J. Integrating mitigation and adaptation as responses to climate change: A synthesis. Mitig. Adapt. Strateg. Glob. Chang. 2007, 12, 957-962. [CrossRef]

12. VenkataRaman, S.; Iniyan, S.; Goic, R. A review of climate change, mitigation and adaptation. Renew. Sustain. Energy Rev. 2012, 16, 878-897. [CrossRef]

13. Asian Development Bank (ADB); Felipe, J.; Estrada, G.B. Why has the Philippines's Growth Performance Improved? From Disappointment to Promising Success; ADB economics working paper series, Number 542; ADB publications: Manila, Philippines, 2018.

14. Webpage for City of Santa Rosa, Province of Laguna. Available online: www.santarosacity.gov.ph/home/ (accessed on 16 August 2018).

15. Zimmer, V.; Bendoricchio, G. Nutrient and suspended solid loads in the Laguna de Bay, Philippines. Water Sci. Technol. 2001, 44, 77-86. [CrossRef] [PubMed]

16. Victoriano, J.M.; Lacatan, L.L.; Vinluan, A.A. Predicting river pollution using random forest decision tree with GIS model: A case study of MMORS, Philippines. Int. J. Environ. Sci. Dev. 2020, 11, 1. [CrossRef]

17. Philippine Atmospheric Geophysical Astronomical Services Administration (PAGASA). 2020. Available online: http://bagong.pagasa.dost.gov.ph/information/climate-philippines (accessed on 12 January 2020).

18. Philippine Statistical Authority (PSA). Philippines in Figures; Databank and information services division: Quezon City, Philippines, 2015; p. 102.

19. Comprehensive Land Use Plan (CLUP) City of Santa Rosa. Comprehensive Land Use Plan (2018-2026); CLUP: City of Santa Rosa, Philippine, 2018.

20. Seiber, J.; Purkey, D. WEAP-Water Evaluation and Planning System User Guide for WEAP 2015; Stockholm Environment Institute: Stockholm, Sweden, 2015.

21. American Public Health Association (APHA). Standard Methods for the Examination of Water and Wastewater, 22nd ed.; Rice, E.W., Baird, R.B., Eaton, A.D., Clesceri, L.S., Eds.; American Public Health Association (APHA), American Water Works Association (AWWA) and Water Environment Federation (WEF): Washington, DC, USA, 2012; p. 1496.

22. United Nations, Department of Economic and Social Affairs, Population Division (UN DESA). World Urbanization Prospects: The 2014 Revision, 2015, (ST/ESA/SER.A/366); United Nations Publication: New York, NY, USA, 2015; p. 517.

23. The United Nations World Water Development Report 2017; Wastewater: The Untapped Resource; UNESCO: Paris, France, 2017.

24. Department of Environment and Natural Resources (DENR). Water Quality Guidelines and General Effluent Standards of 2016; Republic of Philippines: Quezon City, Philippines, 2016; p. 25.

25. Khan, A.A.; Gaur, R.Z.; Diamantis, V.; Lew, B.; Mehrotra, I.; Kazmi, A.A. Continuous fill intermittent decant type sequencing batch reactor application to upgrade the UASB treated sewage. Bioprocess Biosyst. Eng. 2013, 36, 627-634. [CrossRef] [PubMed]

(C) 2020 by the authors. Licensee MDPI, Basel, Switzerland. This article is an open access article distributed under the terms and conditions of the Creative Commons Attribution (CC BY) license (http://creativecommons.org/licenses/by/4.0/). 